\title{
Challenges of Integrating New Technologies for Teaching and Learning in the Business Education Programme of Colleges of Education in South-East Nigeria
}

\author{
Ile Chika Madu, Udegbunam Emmanuel Obidi, Odimmega Chinyere Genevive
}

Vocational Education Department, Faculty of Education, Nnamdi Azikiwe University, Awka, Nigeria

Email address:

ilechika2011@yahoo.com (I. C. Madu), uemmanuelobidi@yahoo.com (U. E. Obidi), chinyere_odimmega@yahoo.com (O. C. Genevive)

\section{To cite this article:}

Ile Chika Madu, Udegbunam Emmanuel Obidi, Odimmega Chinyere Genevive. Challenges of Integrating New Technologies for Teaching and Learning in the Business Education Programme of Colleges of Education in South-East Nigeria. Education Journal. Special Issue: New Dimensions in Vocational Business Education Teaching and Learning. Vol. 4, No. 6-1, 2015, pp. 9-14. doi: 10.11648/j.edu.s.2015040601.12

\begin{abstract}
The study focused on challenges of integrating new technologies for teaching and learning in business education programme at colleges of education in south-east Nigeria. Three research questions guided the study and three hypotheses were tested at 0.05 level of significance. A survey design was adopted. The population consisted of 129 business educators. No sample as taken, as the number was sizeable for the researchers to handle. A structured questionnaire titled "challenges of integrating new technologies for teaching and learning in the business education programme" (CINTTLBEP) was used for data collection. The instrument was validated by three experts in Nnamdi Azikiwe University, Awka. The reliability of the instrument was ensured using test re-test technique. Data collected were analyzed using Pearson Product Moment Correlation Co-efficient formula which yielded reliability co-efficient of 0.88 . Data related to the research questions were analyzed using mean and standard deviation in respect to research questions while, z-test was used to test the hypotheses. It is concluded that new technologies should be provided in colleges of education and business educators should be trained and retrained on the use of these technologies. Based on the findings of the study, it was recommended that government should grant permission to business educators to undertake in-service training locally and internationally and among others.
\end{abstract}

Keywords: Integration, New Technologies, Teaching, Learning and Colleges of Education

\section{Introduction}

Technology has become an integral part of the instructional process resulting in the development of new concepts in the logistics of instruction. The use of Information Communication Technology (ICT) gadgets and machines has made teaching and learning a bit easier, concrete, real and more result-oriented. Since the introduction of ICT, there has been a growing concern for the use of new technologies.

Technology is defined by Redmann and Kotrlik (2008) as the making, modification, usage, and knowledge of tools, machines, techniques, crafts, systems and methods of organization in order to solve a problem, improve a pre-existing solution to a problem, achieve a goal, handle an applied input or output relation or perform a specific function. Technology is ubiquitous, touching almost every part of our lives, our communities, our homes. Yet most schools lag far behind when it comes to integrating technology into classroom learning. Many are just beginning to explore the true potentials technology offers for teaching and learning. When properly used, technology will help students acquire the skills they need to survive in a complex, highly technological knowledge-based economy. Thus, technologies are applied in classroom situation to enhance teaching and learning processes.

Ekpenyong (2004) asserted that old technologies used in teaching have their origin from Paul Frefor banking of knowledge. At the period when educators were seen as the custodians and distributors of knowledge, whatever, the educators said were right and students must follow strictly all the dictates of the teachers. Ekpenyong (2004) condemned these old technologies applied in teaching as it was characterized by fatigue, poor relationship between students and teachers, low motivation for learning, teacher-centered and low retention of knowledge. Therefore, a business educator who has not been trained in the new technologies 
cannot be effective, efficient or able to deliver the knowledge and skills required by the students to succeed in a new work environment that is increasingly ICT based. It is in keeping with the dynamics of social change and the demands on education that the federal government of Nigeria (FRN, 2004) came up with some policy innovations and changes, one of which was the introduction of information and communications technology (ICT) into the school system.

Specifically, business education as a component of vocational technical education programme, prepares individuals for careers in business and to be an intelligent economic consumers of goods and services (Ugwoke, 2011). Therefore, for the business education programme to sustain its relevance in providing the needs of individuals and that of the society, it must embrace current trends in modern technologies in the academic and economic demands of the society.

New technologies in teaching and learning in business education programmes according to Ezenwafor (2012) include:

a) Using broadcast materials or CD-Rom for information collection and storage;

b) Using micro-computers with soft-ware applications to write or produce documents,

c) Skillful keyboarding,

d) E-mail and Messaging,

e) Internet browsing using search engines, windows messenger, yahoo chat room and so on.

f) Using opaque projectors, slide projectors and multimedia projectors.

g) Utilizing e-banking, e-commerce, e-economies, and so on and

h) Utilizing different computer software, and applications such as word processors, spreadsheets, power-point, desktop publishing, and graphics among others.

Other technological devices available for teaching and learning according to Osuala (2009) include media typewriter or processor, video tape recorder, sound on pepper system, e-commerce, advanced calculators, dial access system, digital library, individual audio application and audio-visual retrieval system. Although these technologies are not new in many advanced countries, they are relatively new in Nigeria. While some of them are already being utilized in some schools, they are yet to be used in many of Nigeria's educational institutions.

New technologies in business education programme, according to Achugbue (2011) have posed many challenges to business educators in Nigeria. Achugbue (2011) further opined that business education in colleges of education would achieve the goals of teaching if such modern technological teaching aids like computers, electric typewriters, television sets, projectors, internet facilities, among others are adequately provided and utilized.Many colleges of education do not give adequate priority and attention to the acquisition and utilization of new instructional technologies needed for teaching and learning. The dearth of these facilities makes it difficult to teach and prepare business education students for the use of new technologies now and in future world of work.
However, Reigebuth and Joseph (2002) saw technology integration as focusing on "how" to use technology to support the way teaching and learning is currently being done in schools. It also enhances the use of modern instructional mode of teaching and learning in tertiary institutions to meet the demands of the current trends in academics. Integrating technology into classroom instruction means more than teaching basic computer skills and software programs in a separate computer class. Effective technology integration must happen across the curriculum in ways that deepen and enhance the learning process. In particular, it must support four key components of learning: active engagement, participation in groups, frequent interaction and feedback, and connection to real-world experts. Effective technology integration is achieved when the use of technology is routine and transparent and when technology supports curricula goals. Technology also changes the way teachers teach, offering educators' effective ways to reach different types of learners and assess students' understanding through multiple means. It also enhances the relationship between teachers and students. When technology is effectively integrated into subject areas, teachers become advisers, content experts, and coaches. Technology helps to make teaching and learning more meaningful and fun.

According to Nagel (2013), despite increasingly widespread adoption of technologies in virtually every aspect of education, significant challenges are preventing widespread affective implementation. Nagel observed that key among all the challenges is the lack of sustainable professional development for business educators who are required to integrate the new technologies into classroom practices. It is against this background that this study was carried out to ascertain the challenges of integrating new technologies into the teaching and learning of business education programmes in colleges of education. The study will also try to find out ways of improving the use of new technologies in business education in colleges of education in South-East Nigeria.

\section{Statement of the Problem}

One of the aims of integrating new technologies is to improve the quality of education and expand access to education. The education sector is expected to be technologically driven and requires that technological resources are fully integrated in it. Unfortunately, the education sector seems to be lacking the necessary technological resources needed to bring the Nigerian education sector at par with international standards. Business education programme being a skills development programme seem to be worst hit by the dearth of requisite technological tools on the one hand and the skills needed to effect the integration on the other. The consequence is that the programme is faced with the challenge of producing the needed manpower for the world of work. For technology to be successfully useful and deliver the goods expected of it such as making business education graduates global workers, it should be made part of the educational delivery of learning. 


\section{Purpose of the Study}

The main purpose of this study is to ascertain the challenges of integrating new technologies in teaching and learning in the business education programme in colleges of education in South-East Nigeria. Specifically, the study sought to:

1. Ascertain the availability of new technologies for teaching and learning business education programmes in colleges of education in South-East Nigeria.

2. Ascertain the challenges of integrating the new technologies for teaching and learning business education programmes in colleges of education in South-East Nigeria.

3. Find out the ways of improving the use of new technology for teaching and learning business education programmes in colleges of education in South-East Nigeria.

\section{Research Questions}

The following research questions guided the study.

1. What new technologies are available for teaching and learning business education programmes in colleges of education in South-East-Nigeria?

2. What are the challenges of integrating new technologies for teaching and learning business education programmes in colleges of education in South-East-Nigeria?

3. In what ways can the use of new technologies for teaching and learning business education programmes in colleges of education in South-East Nigeria be improved?

\section{Hypotheses}

The following null hypotheses were tested at 0.05 level of significance

1. There is no significant difference in the mean responses of experienced and less experienced business educators on the challenges of integrating new technologies for teaching and learning business education programmes in colleges of education in South-East Nigeria.

2. There is no significant difference in the mean responses of experienced and less experienced business educators on the ways of improving the use of new technologies for teaching and learning business education programmes in colleges of education in South-East Nigeria.

\section{Method}

Descriptive survey design was adopted for the study. The researchers considered this design appropriate for this study since it intended to collect data from practicing business educators regarding the challenges of integrating new technologies for the teaching and learning business education in colleges of education in South-East Nigeria.
The population for the study consisted of 129 business educators from seven colleges of education that offer business education in south-east Nigeria. The researchers believed that business educators are in a better position to understand and appreciate the challenges militating against the integration of new technologies for teaching and learning business education programmes in colleges of education in South-East Nigeria. No sample was taken for the study because the number was manageable for the researchers to handle.

The instrument for data collection was a structural questionnaire tagged: "Challenges of integrating new technologies for teaching and learning in the business education programmes", (CINTTLBEP). The instrument was validated by three experts, two from the Department of Vocational Education and one from the Department of Education Foundations both at NnamdiAzikiwe University, Awka. Their comments enhanced the content validity of the instrument.

Test re-test method was used to establish the reliability of the instrument, and the Pearson Product Moment Correlation Coefficient was used to test the reliability of the instrument. The analysis yielded a co-efficient of 0.88 indicating that the instrument was reliable for the study.

The administration of the instrument was carried out personally by the researchers with the aid of two research assistants who are business educators. All copies of the questionnaire distributed were retrieved and used for data analysis.

Data collected regarding the research questions were analyzed using percentages for the first research question while, descriptive statistics (mean and standard deviation) were used for research questions 2 and 3 respectively. The z-test was used to analyze the hypotheses. The decision rule regarding the research questions were based on the real limit of numbers as shown in Table 1 below:

Table 1. Decision Rule.

\begin{tabular}{lll}
\hline Response & Mean Point & Boundary Real Limits \\
\hline Strongly Agree & 5 & $4.50-5.00$ \\
Agree & 4 & $3.50-4.49$ \\
Undecided & 3 & $2.50-3.49$ \\
Disagree & 2 & $1.50-2.49$ \\
Strongly Disagree & 1 & $0.50-1.49$ \\
\hline
\end{tabular}

Any item whose mean score was 3.50 above to 5.00 qualify to be accepted. On the other hand, any item with a mean score below 3.50 did not qualify to be accepted.

\section{Results}

\section{Research Question I}

What new technologies are available for teaching and learning business education programmes in colleges of education in South-East Nigeria?

Table 2, shows that items $3,4,6,7,8$, and 9 revealed that majority of the respondents stated that new technologies for 
teaching and learning in business education programme in colleges of education were not available while, only (4) four (item $1,2,5 \& 10$ ) was agreed by the respondents as been available.

Table 2. Percentage scores on the availability of new technologies for teaching and learning business education programmes.

\begin{tabular}{llllll}
\hline S/N & Items & \multicolumn{2}{l}{ Available } & \multicolumn{2}{l}{ Not Available } \\
\hline & & No & $\mathbf{( \% )}$ & No & $\mathbf{( \% )}$ \\
\hline 1 & Desktop computer & 100 & 77.5 & 29 & 22.5 \\
2 & CD-Rom & 110 & 85 & 19 & 15 \\
3 & Multimedia circuit TV & 38 & 29.5 & 91 & 70.5 \\
4 & Closed circuit TV & 29 & 22.5 & 100 & 77.5 \\
5 & Video tape recorder & 93 & 72.1 & 36 & 27.9 \\
6 & E-mail facilities & 39 & 30.2 & 90 & 69.8 \\
7 & E-banking/commerceFacilities & 30 & 23.3 & 99 & 76.7 \\
8 & Media typewriter & 36 & 27.9 & 93 & 72.1 \\
9 & Cyber cafe' Internet & 26 & 20.2 & 103 & 79.8 \\
10 & Audio tape recorder & 105 & 81.4 & 24 & 18.6 \\
\hline
\end{tabular}

\section{Research Question 2}

What are the challenges of integrating new technologies for teaching and learning business education programmes in colleges of education in South-East Nigeria?

Table 3. Mean Score of business educators on the challenges of integrating new technologies for teaching and learning business education programmes.

\begin{tabular}{lllll}
\hline S/N & $\begin{array}{l}\text { Challenges of integrating new } \\
\text { technologies }\end{array}$ & Mean & SD & Remark \\
\hline 1 & Dearth of machine/equipment & 4.42 & 0.79 & Accepted \\
2 & Lack of space/accommodation & 1.96 & 1.13 & Rejected \\
3 & Unsteadyof electricity supply & 4.52 & 0.79 & Accepted \\
4 & Lack of Maintenance & 4.37 & 0.84 & Accepted \\
5 & $\begin{array}{l}\text { Inadequate training opportunities for } \\
\text { Business Educators }\end{array}$ & 4.57 & 0.86 & Accepted \\
6 & $\begin{array}{l}\text { Inability of business educators to } \\
\text { utilize available devices }\end{array}$ & 4.45 & 0.79 & Accepted \\
& Mean of means & 4.41 & 2.10 & \\
\hline
\end{tabular}

Table 3, shows that the business educators generally accepted that all the items listed except one (item 12) were the major challenges of integrating new technologies for teaching and learning business education programmes in colleges of education in South-East Nigeria. This is because their mean scores were above 3.50 which is the cut of point or the boundary real limit. They did not, however, accept lack of space/ accommodation with a mean score of 1.96 as a challenge since they have enough space to accommodate such machines or equipment. The mean of means revealed that most of the items listed were seen as challenges of integrating new technologies with mean of 4.41 .

Research Question 3

What are the ways of improving use of new technologies for teaching and learning business education programmes in colleges of education in South-East Nigeria?

Table 4, shows that all the variables have mean scores above 3.50.The respondents accepted all the items as suitable measures for improving the use of new technologies for teaching and learning business education programmes in colleges of education in South-East Nigeria.
Table 4. Mean Score and Standard deviation of respondents'on the ways of improving the use of new technologies for teaching and learning business education programmes.

\begin{tabular}{|c|c|c|c|c|}
\hline $\mathbf{S} / \mathbf{N}$ & $\begin{array}{l}\text { Ways of improving the use of new } \\
\text { technologies }\end{array}$ & Mean & SD & Remark \\
\hline 17 & Through in-service training & 4.45 & 0.77 & Accepted \\
\hline 18 & Through installation of internet facilities & 4.26 & 0.85 & Accepted \\
\hline 19 & Through provision of electricity & 4.39 & 0.82 & Accepted \\
\hline 20 & $\begin{array}{l}\text { Through workshop/seminar in } \\
\text { relevantareas }\end{array}$ & 4.10 & 2.07 & Accepted \\
\hline 21 & $\begin{array}{l}\text { Private sector should be partnered with to } \\
\text { invest in the provision of new } \\
\text { technologies for business education }\end{array}$ & 4.67 & 0.55 & Accepted \\
\hline 22 & $\begin{array}{l}\text { Business educators should demonstrate } \\
\text { competencies in using new technologies }\end{array}$ & 4.61 & 0.66 & Accepted \\
\hline 23 & $\begin{array}{l}\text { There should be adequate new } \\
\text { technologies }\end{array}$ & 4.26 & 0.93 & Accepted \\
\hline 24 & $\begin{array}{l}\text { There should be functional new } \\
\text { technologies }\end{array}$ & 4.10 & 1.00 & Accepted \\
\hline 25 & Provision of Digital Library & 4.48 & 0.83 & Accepted \\
\hline 26 & $\begin{array}{l}\text { There should be a law to enforce } \\
\text { maintenance of new technologies for } \\
\text { business education }\end{array}$ & 4.36 & 0.80 & Accepted \\
\hline 27 & $\begin{array}{l}\text { Employment of business educators } \\
\text { should be based on demonstrable } \\
\text { competencies in new technologies }\end{array}$ & 4.53 & 0.91 & Accepted \\
\hline \multirow[t]{2}{*}{28} & $\begin{array}{l}\text { Availability of enough computers and } \\
\text { accessories }\end{array}$ & 3.92 & 1.37 & Accepted \\
\hline & Mean of means & 4.66 & 2.16 & \\
\hline
\end{tabular}

\section{Test of Hypotheses}

\section{Hypothesis 1}

There is no significant difference in the mean responses of experienced and less experienced business educators on the challenges of integrating new technologies for teaching and learning business education programmes in colleges of education in South-East Nigeria.

Table 5. Summary of z-test on the responses of experienced and less experienced Business Educators in the seven colleges of Education in south-east Nigeria on the challenges of integrating new technologies for teaching and learning.

\begin{tabular}{|c|c|c|c|c|c|c|c|c|}
\hline & & & & & & & & $\mathrm{N}=129$ \\
\hline $\begin{array}{l}\text { Business } \\
\text { Educators } \\
\end{array}$ & $\mathbf{N}$ & $\mathbf{X}$ & SD & Df & z-cal & $\alpha$ & z-crit & Remark \\
\hline \multirow[t]{2}{*}{ Experienced } & 76 & 4.37 & 0.86 & & & & & \\
\hline & & & & 127 & -1.39 & 0.05 & 1.96 & Significant \\
\hline $\begin{array}{l}\text { Less } \\
\text { Experienced }\end{array}$ & 53 & 4.47 & 0.79 & & & & & \\
\hline
\end{tabular}

Table 5, shows that the z-calculated of -1.39 is less than the $\mathrm{z}$-critical value of 1.96 at 127 degree of freedom at 0.05 level of significance. Since the $z$-calculated value is less than the $\mathrm{z}$-critical value, the null hypothesis is accepted. This implies, therefore, that there is no significant difference in the mean ratings of experienced and less experienced business educators on the challenges of integrating new technologies for teaching and learning business education programmes in colleges of education in South-East Nigeria. The null hypothesis was therefore, accepted while the alternate hypothesis was not accepted. 


\section{Hypothesis 2}

There is no significant difference in the mean responses of experienced and less experienced business educators on the ways of improving the use of new technologies for teaching and learning business education programmes in colleges of education in South-East Nigeria.

Table 6. Summary of z-test on the responses of experienced and less experienced Business Educators in the seven colleges of Education in south-east Nigeria on the ways of improving the use of new technologies for teaching and learning.

\begin{tabular}{lllllllll}
\hline & & & & & & & & $\mathbf{N}=129$ \\
\hline $\begin{array}{l}\text { Business } \\
\text { educators }\end{array}$ & $\mathbf{N}$ & $\mathbf{X}$ & SD & Df & z-cal & $\boldsymbol{\alpha}$ & z-crit & Remark \\
\hline Experienced & 76 & 4.71 & 0.46 & & & & & \\
& & & & 127 & 1.65 & 0.05 & 1.96 & Significant \\
$\begin{array}{l}\text { Less } \\
\text { Experienced }\end{array}$ & 53 & 4.58 & 0.69 & & & & & \\
\hline
\end{tabular}

Table 6, shows that the z-calculated value of 1.65 is less than the critical z-value of 1.96 at 127 degree of freedom at 0.05 level of significance. Since the $z$-calculated value is less than the $\mathrm{z}$-critical value, the null hypothesis is accepted. This implies, therefore, that there is no significant difference in the respondents' mean ratings on the ways of improving the use of new technologies for teaching and learning business education programmes in colleges of education in South-East Nigeria. The null hypothesis was therefore, accepted while the alternate hypothesis was not accepted.

\section{Discussion of Findings}

It was revealed in this study that new technologies like desktop computer, CD-Rom, video tape recorder and audio tape recorder were available while, technologies such as: multimedia circuit TV, closed circuit TV, e-mail facilities, e-banking/commerce facilities, media typewriter and cyber café internet were not available. These results agreed with the views of Osuala (2009) and Ezenwafor (2012) who observed that most of the new technologies were not available in colleges of education in South-East Nigeria. The findings also agreed with the opinion expressed in Federal Government of Nigeria (FRN, 2004) that students are only taught theory without the practical aspect of the courses.

The study also revealed that the business educators generally accepted that all the items listed except lack of space/accommodation as major challenges of integrating the new technologies for teaching and learning business education programme in colleges of education in South-East Nigeria. This is because the mean scores were above 3.50 which was the cut of point or the boundary real limit. The first hypothesis revealed that there was no significant difference in the mean ratings of respondents on the challenges of integrating new technologies for teaching and learning business education programme.

Finally, the study also revealed that business educators accepted all the suggested ways as suitable measures for improving the use of new technologies for teaching and learning business education programme in colleges of education in South-East Nigeria. The test of the second hypothesis revealed that there was no significant difference in respondents' mean ratings on the ways of improving the use of new technologies for teaching and learning business education programme.

\section{Conclusion}

Based on the findings of the study, it is concluded that new technologies have been recognized as very vital in adding easy teaching and learning in the educational system. Information technologies have always held great promise for transforming our teaching, thinking and learning. Inspite of the importance of new technologies in educational sector vis-s-vis the business education programme, there are quite a number of challenges associated with the use of technologies in teaching and learning of business education programmes in colleges of education in South East Nigeria. Some of them are: dearth of machine/equipment, unsteady electricity supply, lack of maintenance, inadequate training opportunities for business educators and inability of business educators to utilize the available devices. Finally, ways of improving on the use of new technologies were also highlighted which include: through in-services training, through installation of internet facilities, through provision of electricity supply and through organizing workshops/seminars in related areas among others.

\section{Recommendations}

In the view of findings and conclusion of the study, it is recommended that:

1. The government should grant permission to business educators to undertake on in-service trainings (whether locally or intentionally), workshops, seminars and conferences in order to keep them abreast with the use of the new technologies.

2. The curriculum of business education in universities should be enriched to include topics in information and communication technology, data management, web page design among others at all level or classes. This will help enrich the knowledge and the skill base of the students during training and prepare them adequately for the world of work.

3. Relevant equipment and machines should be provided to enhance teaching and learning of business education programmes in all tertiary institutions.

\section{References}

[1] Achugbue I. E. (2011). The relevance of information and communication technology in Nigeria Universities. Research in Education 17 (1), 146 - 152.

[2] Ekpenyong, L. E. (2004). Mimeography on advance curriculum in Education, Faculty of Education, University of Benin, Benin City. 
[3] Ezenwafor, J. I. (2012). Adequacy of exposure to information and communication technology by graduating business education students of tertiary institutions in Anambra State. Business Education Journal: Association of Business educators of Nigeria. VIII (2), $45-60$.

[4] Federal Republic of Nigeria (2004 Revised). National Policy on Education Lagos: NERDC Press.

[5] Nagel, D. (2013). Challenges of technology, Retrieved $6^{\text {th }}$ October 2014 from www.journal.com/article.

[6] Nworgu, B. G. (2006). Educational Research: Basic Issues \& Methodology. Enugu; University Trust Publishers.

[7] Osuala, E. C. (2009) Business and computer education. Enugu: Cheston Agency Limited.
[8] Redmann, D. \&Kotrlik, J. (2008). A trend study: Technology adoption in the teaching -learning process by secondary business teachers - 2012 and 2007. The Delta Pi Espositon Journal, 1(2), 77 -89.

[9] Reigeluth, C. \& Joseph, R. (2002). "Beyond technology integrating: the case for technology transformation". Educational Technology Journal, 42(4), 9-14.

[10] Ugokwe, E. O. (2011). Effective utilization of ICT for repositioning business education programme in tertiary institutions in Nigeria for national development. International Journal of Educational Research. 11(1), 20-24. 